\title{
Kajian Yuridis Putusan Mahkamah Agung Dalam Penyelesaian Sengketa Pada \\ Perusahaan Leasing Dengan Badan Penyelesaian Sengketa Konsumen
}

(Studi Kasus Putusan Mahkamah Agung Nomor 210 K/Pdt.Sus-BPSK/2015)

\author{
Agustine Azizah* \\ Universitas Surabaya, Indonesia \\ sashaagustine15@gmail.com*
}

\begin{abstract}
The purpose of this study for reviewed the dispute resolution between the finance company and the consumer decided by BPSK in the case of Supreme Court Decision Number 210 K/Pdt.Sus-BPSK/2015 and examine the consideration of the Supreme Court Judge stating that BPSK is not authorized to decide case in between consumer financing companies.This research is normative descriptive who use secondary data and collecting data use literature study. Data analysis use interactive model.The result of the research indicates that the Supreme Court Decision Number 210 K/Pdt.Sus- BPSK/2015 in the case of special dispute on consumer dispute between First Indo American Leasing Branch Bandung ("First Indo Finance") with BPSK Bandung and Neva Rahmansyah, SE stated that The Supreme Court rejected the appeal from the First Appeal Applicant of PT First Indo American Leasing Bandung ("First Indo Finance") and amended the decision of Bandung District Court Number 461/Pdt.G/2014/PN Bdg. dated December 24, 2014 so that it is clear that the Supreme Court accepted the exception of the petitioners and stated that BPSK is not authorized to examine and adjudicate the case and to punish the Cassation Applicant Applicant to pay the court fee in the appeal level stipulated at Rp 500,000 (five hundred thousand rupiahs). Consideration of the Supreme Court Judge stating that BPSK is not authorized to decide the case in the case between the finance company and the consumer because the legal relationship between the Plaintiff and the Defendant constitutes a joint financing agreement with the fiduciary transfer of property, which implements civil law relationships and does not include consumer disputes as provided in the Act Number 8 Year 1999 on Consumer Protection so that the dispute arising from the implementation of the consumer financing agreement is a dispute agreement which is the authority of the District Court
\end{abstract}

Key Words: The Great Court off The Dispute Settlement; Leasing Company; Complete Agency Consumer Dispute

Abstrak: Tujuan penelitian ini untuk mengkaji penyelesaian sengketa antara perusahaan pembiayaan dan konsumen yang diputuskan oleh BPSK dalam perkara Putusan Mahkamah Agung Nomor 210 K/Pdt.Sus-BPSK/2015 dan mengkaji pertimbangan Hakim Mahkamah Agung yang menyatakan bahwa BPSK tidak berwenang memutus perkara di antara perusahaan pembiayaan konsumen. Penelitian ini bersifat deskriptif normatif yang menggunakan data sekunder dan pengumpulan data menggunakan studi kepustakaan. Analisis data menggunakan model interaktif. Hasil penelitian menunjukkan bahwa Putusan Mahkamah Agung Nomor 210 K/Pdt.Sus-BPSK/2015 dalam perkara sengketa khusus sengketa konsumen antara First Indo American Leasing Cabang Bandung ("First Indo Finance" ) dengan BPSK Bandung dan Neva Rahmansyah, SE menyatakan bahwa Mahkamah Agung menolak kasasi dari Pemohon Banding Pertama PT First Indo American Leasing Bandung ("First Indo Finance") dan mengubah putusan Pengadilan Negeri Bandung Nomor 461/Pdt.G /2014/PN Bdg. tanggal 24 Desember 2014 sehingga jelas Mahkamah Agung menerima eksepsi para pemohon dan menyatakan bahwa BPSK tidak berwenang memeriksa dan mengadili perkara serta menghukum Pemohon Kasasi untuk membayar biaya perkara di tingkat kasasi yang ditetapkan sebesar Rp 500.000 (lima ratus ribu rupiah). Pertimbangan Hakim Agung yang menyatakan bahwa BPSK tidak berwenang memutus perkara antara perusahaan pembiayaan dan konsumen karena hubungan hukum 
antara Penggugat dan Tergugat merupakan perjanjian pembiayaan bersama dengan penyerahan harta secara fidusia, yang dilaksanakan hubungan hukum perdata dan tidak termasuk sengketa konsumen sebagaimana diatur dalam Undang-Undang Nomor 8 Tahun 1999 tentang Perlindungan Konsumen sehingga sengketa yang timbul dari pelaksanaan perjanjian pembiayaan konsumen merupakan sengketa perjanjian yang menjadi kewenangan Pengadilan Negeri

Kata kunci: Mahkamah Agung; Perusahaan Leasing; Penyelesaian Sengketa Konsumen Agensi

\section{Pendahuluan}

Kebutuhan masyarakat terhadap sarana transportasi pada umumnya semakin meningkat dalam upaya menunjang aktifitas sehari-hari, Salah satu penunjang kebutuhan yang paling utama pada saat ini ialah kendaraan baik roda empat maupun roda dua, Namun karena harga kendaraan roda empat maupun roda dua tidak dapat dijangkau oleh sebagian masyarakat, sehingga pada saat ini untuk dapat menikmatinya dapat dilakukan dengan cara kredit melalui perusahaan pembiayaan dengan system leasing, dalam leasing system yang digunakan yaitu perjanjian sewa beli dimana sebelum pelunasan terakhir status pembeli adalah penyewa bukan pemilik.

Istilah leasing berasal dari kata lease, yang berati sewa menyewa dan merupakan suatu bentuk derivative dari sewa menyewa. Dalam dunia bisnis istilah ini kembang dalam bentuk khusus yang disebut leasing dan kadang-kadang disebut juga lease setelah berubah fungsinya menjadi salah satu jenis pembiayaan. ${ }^{1}$ Dasarnya tujuan utama dari institusi leasing adalah memperoleh hak untuk memakai benda dari milik orang lain. ${ }^{2}$ Sebelum mengadakan kegiatan leasing ini, para pihak akan membuat suatu kontrak yang mengikat. ${ }^{3}$ Leasing adalah perjanjian antara lessor dan lessee untuk menyewa suatu jenis barang tertentu yang dipilih/ditentukan oleh lessee. Hak pemilikan atas barang modal tersebut berdasarkan pembayaran uang sewa yang telah ditentukan dalam suatu Fenomena jual beli dengan sistem kredit (sewa beli), kendaraan bermotor menjadi menarik dari perpektif yuridis karena status pembeli sebelum cicilan terakhir adalah penyewa. Status pembeli baru menjadi pemilik pada saat pelunasan maka hak milik barang berpindah kepada pembeli.

Leasing diatur dalam Peraturan Presiden Nomor 9 tahun 2009 tentang Lembaga Pembiayaan (Perpres 9/2009). Pasal 1 angka 5 Perpres 9/2009 tentang Perusahaan Pembiayaan mendefinisikan sewa guna usaha adalah (leasing) adalah kegiatan pembiayaan dalam bentuk penyediaan barang modal baik secara sewa guna usaha dengan hak opsi (finance lease) maupun sewa guna usaha tanpa hak opsi (operating lease) untuk digunakan oleh penyewa guna usaha (lessee) selama jangka waktu tertentu berdasarkan pembayaran secara angsuran. ${ }^{4}$

Leasing adalah kegiatan pembiayaan yang dilakukan antara lembaga pembiayaan (lessor) dengan seseorang/ pengusaha (lessee) dan bekerja sama dengan pihak supplier/dealer, dalam bentuk penyediaan barang modal baik secara sewa guna usaha dengan

\footnotetext{
${ }^{1}$ Munir Fuady, (2014). Hukum Tentang Pembiayaan, Cet.5, Bandung: PT Citra Aditya Bakti, p.7.

${ }^{2}$ Richard Burton Simatupang. (2003). Aspek Hukum Dalam Bisnis, Cet.2, Jakarta: Rineka Cipta, p. 141.

${ }^{3}$ Ibid, p. 98

${ }^{4}$ Pasal 1 angka 5 Perpres Nomor 9 tahun 2009
} 
hak OPSI (finance lease) maupun sewa guna usaha tanpa hak OPSI (operating lease) untuk di gunakan oleh lessee selama jangka waktu tertentu berdasarkan pembayaran secara berkala. ${ }^{5}$ Adanya Leasing secara otomatis memudahkan pengusaha dalam mengembangkan usahanya, hal ini yang membuat persaingan antara perusahaan leasing di Indonesia saling berlomba dalam memberikan kemudahan kepada konsumen (lesssee) dalam proses pembiayannya.

Perjanjian pembiayaan tidak terlepas dari aspek-aspek hukum yang mengikat antara konsumen dengan perusahaan pembiayaan konsumen tersebut. Perjanjian pembiayaan konsumen dibuat secara baku yaitu isi perjanjian telah disusun secara sepihak oleh perusahaan, sehingga pihak perusahaan dapat menerapkan kebijakan take it or leave artinya bahwa isi perjanjian sudah tidak dapat ditawar lagi, apabila konsumen setuju dengan perjanjian silahkan ambil, kalau tidak setuju silahkan mencari lembaga pembiayaan lain.

Pembiayaan yang diberikan oleh perusahaan Leasing maka cenderung menerapkan perjanjian hutang piutang yang bersifat adanya penggunaan jaminan kepada para konsumennya, hal ini kerap dilakukan mengingat agar terciptanya jaminan para konsumen untuk dapat melunasi hutangnya, dan dalam melakukan perjanjian hutang piutang tersebut kebanyakan para pelaku usaha dalam dunia Leasing menggunakan perjanjian baku atau dapat dikatakan perjanjian yang dibuat secara sepihak, mengingat kebanyakan dalam kondisi yang lemah para konsumen acap kali tidak bisa berbuat apa apa dan cenderung disebut sebagai pihak yang tersisihkan haknya sebagai konsumen, karena faktor kebutuhan maupun ekonomi yang sudah mendesak para konsumenpun menyetujui draf-draf perjanjian atau klausula baku tersebut.

Persoalan yang muncul dalam perjanjian lembaga pembiayaan konsumen umumnya adalah wanprestasi, dimana pada kenyataannya ada banyak konsumen yang tidak memperhatikan ketentuan-ketentuan yang telah disepakati bersama dengan pihak leasing, banyak konsumen yang tidak membaca ketentuan yang disepakati, sehingga ketika terjadi wanprestasi konsumen sering berpikir bahwa pihak leasing telah melakukan penggelapan atau pencurian kendaraan dan melaporkan pihak leasing kepada Kepolisian Republik Indonesia, selain itu ada juga konsumen yang berpikir mereka telah membayar cicilan hingga telah melunasi pokok dan tinggal cicilan bunga, namun mereka tidak sadari bahwa pada perjanjian yang telah disepakati telah menggaturnya tidak ada alasan untuk konsumen bisa melakukan wanprestasi sedikit pun. Hak konsumen dapat dilindunggi apabila pihak konsumen tidak melakukan wanprestasi, tetapi kalau konsumen melakukan wanprestasi sulit untuk melakukan perlindungan kecuali pihak pelaku Usaha tidak melaksanakan kewajibanya sesuai dengan Undang-Undang No 8 tahun $1999 .^{6}$

Debitur yang lalai mengembalikan uang pinjaman pada saat yang ditentukan. Sesuai dengan perjanjian pembiayaan konsumen dan perjanjian jual beli yang telah dilaksanakan, pihak konsumen membayar harga barang kepada perusahaan pembiayaan konsumen secara angsuran sampai lunas. Sebelum pembayaran lunas, semua dokumen kepemilikan atas barang dikuasai oleh perusahaan pembiayaan konsumen sebagai jaminan secara fidusia. Apabila Konsumen melakukan wanprestasi dalam arti tidak mampu lagi membayar (macet), maka

5 Abdulkadir Muhammad, (1992). Perjanjian Baku Dalam Praktek Perusahaan Perdagangan. Bandung: PT. Citra Aditya Bakti, p. 144

${ }^{6}$ Demy Amelia Amanda Manalip, (2017). Perlindungan Hukum Terhadap Konsumen dalam Penarikan Kendaraan Bermotor yang Dilakukan oleh Perusahaan. Lex Administratum, Vol. V No. 3, E-Jurnal UNSRAT, Manado, Sulawesi Utara, p. 43. 
perusahaan pembiayaan konsumen berdasarkan kuasa untuk menjual, melakukan penjualan barang guna menutup hutang konsumen yang belum dilunasi.

Pasal 3 Peraturan Menteri Keuangan No.130/PMK.010/2012 menyatakan bahwa perusahaan pembiayaan dilarang melakukan penarikan benda jaminan fidusia berupa kendaraan bermotor apabila Kantor Pendaftaran Fidusia belum menerbitkan sertifikat jaminan fidusia dan menyerahkannya kepada perusahaan pembiayaan. ${ }^{7}$ Dengan pemenuhan syarat tersebut maka baru boleh dilaksanakan penarikan benda fidusia sebagai jaminan atas utang yang telah digunakan pemberi fidusia. Dalam suatu perjanjian (kredit), kreditur (perusahaan leasing) meminta jaminan berupa fidusia atas obyek perjanjian tersebut. Tentunya dengan harapan agar objek perjanjian dapat dieksekusi dengan cara fidusia jika jalan lain tidak bisa dicapai. Pengaturan fidusia ini bersatu dalam perjanjian pengakuan hutang walaupun dibuat akta tersendiri dalam untuk fidusia ini. ${ }^{8}$

Apabila angsuran kendaraan bermotor tersebut tertunda, seringkali tanpa surat peringatan terlebih dahulu, perusahaan pembiayaan mengambil paksa kendaraan bermotor yang menjadi objek perjanjian. Bahkan kadang- kadang pihak perusahaan menggunakan tenaga penagih hutang yang kerapkali memaksa konsumen dengan cara kekerasan. Dalam hal ini kedudukan konsumen sangat lemah, karena konsumen telah kehilangan sejumlah uang yang telah dibayarkan kepada perusahaan pembiayaan. Menurut perjanjian pembiayaan, konsumen telah melepaskan haknya untuk mengajukan keberatan atas penarikan kendaraan, penghitungan hasil penjualan kendaraan yang ditarik, potongannya serta jumlah hutang atau sisa hutang bunga dan biaya lain-lainnya, termasuk denda- denda dan biaya pengambilan (penarikan) dan penjualan kembali kendaraan.

Konsumen yang mempunyai posisi tawar lemah perlu mendapatkan perlindungan. UU No 8 Tahun 1999 Tentang Perlindungan Konsumen (UUPK) mengatur bahwa apabila terjadi sengketa konsumen, penyelesaiannya dapat dilakukan antara lain melalui lembaga yang dinamakan Badan Penyelesaian Sengketa Konsumen (BPSK), Pengadilan Negeri hingga Mahkamah Agung. BPSK adalah menyelesaikan sengketa konsumen di luar pengadilan. BPSK berfungsi sebagai instrumen hukum penyelesaian sengketa di luar pengadilan yaitu melalui konsiliasi, mediasi, dan arbitrase. Selain itu fungsi BPSK adalah melakukan pengawasan terhadap pencantuman klausula baku oleh pelaku usaha, termasuk didalamnya klausula baku yang dikeluarkan oleh perusahaan leasing.

Undang-undang Nomor 8 Tahun 1999 membentuk suatu lembaga dalam hukum perlindungan konsumen yaitu Badan Penyelesaian Sengketa Konsumen (BPSK). Pasal 1 angka 11 UUPK menyatakan bahwa BPSK adalah badan yang bertugas menangani dan menyelesaikan sengketa antara pelaku usaha dan konsumen. ${ }^{9}$ Dalam Pasal 49 ayat (1) disebutkan bahwa BPSK dibentuk untuk menyelesaikan sengketa konsumen di luar pengadilan. Pembentukan BPSK sendiri didasarkan pada adanya kecenderungan masyarakat yang segan untuk beracara di pengadilan karena posisi konsumen yang secara sosial dan financial tidak seimbang dengan pelaku usaha. ${ }^{10}$

\footnotetext{
${ }^{7}$ Pasal 3 Peraturan Menteri Keuangan No.130/PMK.010/2012

${ }^{8}$ Fahreza Surya Sumantri, dkk, (2013). Penyelesaian Sengketa Antara PT. Astra Credit Companies dengan Konsumen dalam Perjanjian Leasing, Vol 1 No 3, Malang: Diponegoro Law Review, p. 6.

${ }^{9}$ Pasal 1 angka 1 UUPK

${ }^{10}$ Susanti Adi Nugroho, (2008). Proses Penyelesaian Sengketa Konsumen Ditinjau Dari Hukum Acara Serta Kendala Implementasinya. Jakarta: Kencana, p 75.
} 
Konsumen yang dirugikan oleh perusahaan leasing secara moril, materil dan tidak terpenuhinya hak sebagai konsumen dapat mengajukan permohonan penyelesaian sengketa ke BPSK dengan mengisi formulir, konsumen wajib menandatangani formulir kemudian BPSK memberikan bukti tanda terima kepada konsumen.

Berdasarkan pemikiran di atas, maka penulis merumuskan masalah yang dibahas dalam penelitian antara lain: Bagaimanakah penyelesaian sengketa antara perusahaan pembiayaan dengan konsumen yang diputuskan oleh BPSK dalam perkara Putusan Mahkamah Agung Nomor 210 K/Pdt.Sus-BPSK/2015; dan Apa pertimbangan Hakim Mahkamah Agung yang menyatakan bahwa BPSK tidak berwenang memutuskan perkara dalam kasus antara perusahaan pembiayaan dengan konsumen.

\section{Metode}

Tujuan penelitian ini untuk mengkaji penyelesaian sengketa antara perusahaan pembiayaan dan konsumen yang diputuskan oleh BPSK dalam perkara Putusan Mahkamah Agung Nomor 210 K/Pdt.Sus-BPSK/2015 dan mengkaji pertimbangan Hakim Mahkamah Agung yang menyatakan bahwa BPSK tidak berwenang memutus perkara di antara perusahaan pembiayaan konsumen. Penelitian ini bersifat deskriptif normatif yang menggunakan data sekunder dan pengumpulan data menggunakan studi kepustakaan. Analisis data menggunakan model interaktif. Penelitian ini dikaji dengan mengunakan peraturan perundang-undangan yang berlaku, antara lain Perpres 9/2009, Undang-Undang No 8 tahun 1999, Peraturan Menteri Keuangan No.130/PMK.010/2012, PERMA Nomor 1 Tahun 2006, KUHPerdata, dan juga dengan mengunakan beberapa literatur dan jurnal-jurnal yang dapat mendukung penelitian pada kasus tersebut.

\section{Hasil dan Pembahasan}

\section{Putusan BPSK dalam Perkara Putusan Mahkamah Agung Nomor 210 K/Pdt.Sus- BPSK/2015}

Pihak yang bersengketa dalam penelitian ini adalah PT First Indo American Leasing Cabang Bandung ("First Indo Finance") selaku Pemohon Kasasi melawan Badan Penyelesaian Sengketa Konsumen (BPSK) Kota Bandung dan Neva Rahmansyah, S.E, sebagai para Termohon Kasasi dahulu Termohon dan Turut Termohon. Kasus ini bermula dari adanya putusan BPSK yang mengabulkan guguatan dari penggugat Neva Rahmansyah, SE atas perjanjian leasing mobil Merek Daihatsu/Daihatsu Xenia Tahun 2009 dimana Penggugat juga berkewajiban membayar sisa utang Penggugat kepada Tergugat sebesar Rp50.000.000,00 (lima puluh juta rupiah) yang akhirnya tergugat melakukan kasasi ke Mahkamah Agung, dimana putusan akhir Mahkamah Agung adalah menerima ak eksepsi Turut Termohon dan menyatakan bahwa BPSK tidak berwenang memeriksa dan mengadili perkara tersebut serta menghukum Pemohon Kasasi/Pemohon untuk membayar biaya perkara dalam tingkat kasasi yang ditetapkan sebesar Rp500.000,00 (lima ratus ribu rupiah);

\section{ANALISIS}


Penyelesaian sengketa antara perusahaan pembiayaan dengan konsumen yang diputuskan oleh BPSK dalam perkara Putusan Mahkamah Agung Nomor 210 K/Pdt.SusBPSK/2015 yaitu menolak permohonan kasasi dari Pemohon Kasasi PT First Indo American Leasing Cabang Bandung ("First Indo Finance") dan memperbaiki amar putusan Pengadilan Negeri Bandung Nomor 461/Pdt.G/2014/PN Bdg. tanggal 24 Desember 2014 dengan melengkapi amar putusan yaitu menerimaeksepsi Turut Termohon. Mahkamah Agung menyatakan bahwa putusan Pengadilan Negeri Bandung Nomor 461/Pdt.G/2014/PN Bdg. tanggal 24 Desember 2014 tidak bertentangan dengan hukum dan/atau undang-undang.

Berdasarkan hal tersebut maka menurut penulis apabila ditinjau dari sisi aturannya berdasarkan gugatan yangdiajukan ke BPSK Kota Bandung, dimana BPSK Kota Bandung telah menerima pengaduan dari konsumen, dan secara hukum sebagaimana diatur dalam Pasal 52 huruf $\mathrm{f}$ UUPK, BPSK bertugas dan berwenang melakukan penelitian dan pemeriksaan terhadap sengketa yang diajukan oleh konsumen, kemudian BPSK Kota memanggil Pemohon berdasarkan tugas dan wewenang dari BPSK yang tertuang dalam Pasal 52 huruf g yakni memanggil pelaku usaha yang diduga telah melakukan pelanggaran terhadap perlindungan konsumen, selain itu BPSK Kota Bandung dan dengan berdasarkan Pasal 55 Undang-undang Perlindungan Konsumen, maka BPSK wajib mengeluarkan putusan paling lambat 21 (dua puluh satu) hari kerja setelah gugatan diterima. Hal ini menurut penulis bahwa sudah seharusnya putusan Badan Penyelesaian Sengketa Konsumen Nomor 018/G/VIII/2014/BPSK.BDG tanggal 17 September 2014 dikeluarkan oleh BPSK.

Pasal 56 ayat (2) menyebutkan bahwa Pemohon mengajukan keberatan pada masa tenggang 14 (empat belas) hari kerja setelah menerima pemberitahuan putusan tersebut. Berdasarkan rentetan peristiwa tersebut maka Pemohon Kebaratan sangat keberatan dengan menyelesaikansengketa hingga timbulnya putusan oleh Badan Penyelesaian Sengketa Konsumen Kota Bandung, kemudian Pemohon Keberatan mendaftarkan permohonan keberatan di Pengadilan Negeri Bandung dengan alasan bahwa penggugat adalah konsumen yang tidak memiliki itikad baik serta beberapa keberatan yang lain.

Adanya Perkara Putusan No. 461/Pdt.G/2014/PN. Bdg ini sehingga dapat disimpulkan bahwasanya perkara keberatan terhadap putusan BPSK merupakan hal lumrah yang memiliki dasar hukumnya, yaitu pada Pasal 56 Undang-undang Perlindungan Konsumen yang memaparkankan dibolehkannya mengajukan keberatan jika masih dalam tenggang waktu yang diperbolehkan yakni paling lambat 14 (empat belas) hari setelah menerima pemberitahuan putusan. Terkait persyaratan pengajuan keberatan yang dipaparkan dalam Pasal 6 PERMA Nomor 1 Tahun 2006 Tentang Tata Cara Pengajuan Keberatan Terhadap Putusan BPSK, keberatan tersebut telah memenuhi syarat yakni putusan arbitrase yang dikeluarkan oleh BPSK dianggap sangat merugikan Pemohon yaitu bahwa Pemohon keberatan sama sekali tidak pernah menyetujui untuk penyelesaian sengketa di BPSK Kota Bandung, serta keputusan BPSK tersebut dianggap telah mengesampingkan prosedural formal yang telah ditentukan dalam peraturan perundang- undangan. Peluang keberatan tersebut terbuka lebar demi keadilan yang dicari. Keberatan itu pun tidak dapat dikatakan sebagai gugatan baru maupun banding, melainkan sebuah upaya hukum untuk mencapai putusan yang berkekuatan hukum tetap dan terciptanya suatu kepastian hukum. Hal ini karena Pemohon Keberatan tidak pernah menyetujui penyelesaian melalui badan penyelesaian sengketa konsumen kota Bandung yang seharusnya merupakan kesepakatan 
oleh kedua belah pihak sesuai dengan Perjanjian yang menyatakan dalam hal para pihak telah menyetujui bahwa sengketa di antara mereka akan diselesaikan dengan memilih domisili hukum di Pengadilan Negeri Jakarta. Sehingga, pemohon beranggapan bahwa hanya Pengadilan Negeri Jakarta yang berwenang mengadili perkara ini serta putusan arbitrase ini secara hukum juga telah melanggar salah satu syarat dari pelaksanaan arbitrase, yaitu penyelesaian sengketa arbitrase hanya dapat terjadi apabila adanya kesepakatan antara pihakpihak baik secara tertulis maupun secara lisan. ${ }^{11}$

Penyelesaian Sengketa antara perusahaan pembiayaan dengan konsumen yang diputuskan oleh BPSK dalam perkara Putusan Mahkamah Agung Nomor $210 \mathrm{~K} / \mathrm{Pdt}$.SusBPSK/2015 menunjukkan bahwa Mahkamah Agung menerima eksepsi termohon sekaligus memperkuat putusan dari Pengadilan Negeri Bandung dimana permohonan keberatan yang dilakukan oleh PT. First Indo American Leasing Cabang Bandung ("First Indo Finance") telah lewat waktu dimana Penggugat dalam hal ini (PT Firstindo Finance Cabang Bandung) mengajukan keberatan atas putusan BPSK tertanggal 7 September 2014 Nomor Perkara 018/G/VIII/2014/BPSK.BDG ke Pengadilan Negeri Bandung tetapi melakukan pendaftaran keberatan ke Pengadilan Negeri Bandung tertanggal 9 Oktober 2014; Hal tersebut bertentangan dengan Undang Undang Nomor 8 Tahun 1999 Tentang Perlindungan Konsumen dimana pada Pasal (1) menyatakan bahwa dalam waktu paling lambat 7 (tujuh) hari kerja sejak menerima putusan Badan Penyelesaian Sengketa Konsumen sebagaimana dimaksud dalam Pasal 55 pelaku usaha wajib melaksanakan putusan tersebut sedangkan Pasal (2) para pihak dapat mengajukan keberatan kepada Pengadilan Negeri paling lambat 14 (empat belas) hari kerja setelah menerima pemberitahuan putusan tersebut, sehingga penggugat telah melebihi ketentuan UU dalam mengajukan keberatan.

Keberatan yang diajukan juga bertentangan dengan ketentuan Pasal 179 ayat (2) HIR jo. Pasal 8 Perma Nomor 1 Tahun 2006 tentang Tata Cara Pengajuan Keberatan Terhadap Putusan BPSK, keberatan diajukan telah lewat waktu, sehingga menurut Peneliti bahwa Putusan Pengadilan Negeri dan juga Mahkamah Agung telah tepat keberatan Pemohon dalam perkara tersebut dinyatakan tidak dapat diterima karena telah lewat waktu.

\section{Pertimbangan Hakim Mahkamah Agung yang menyatakan bahwa BPSK tidak berwenang memutuskan perkara dalam kasus antara perusahaan pembiayaan dengan konsumen}

Putusan Mahkamah Agung dalam kasus penyelesaian sengketa antara perusahaan pembiayaan dengan konsumen yang diputuskan oleh BPSK memutuskan bahwa Mahkamah Agung menerima eksepsi dari Turut Termohon dan menyatakan bahwa BPSK tidak berwenang memeriksa dan mengadili perkara tersebut. Menurut peneliti bahwa putusan Mahkamah Agung tersebut sudah tepat karena dalam kasus tersebut Mahkamah Agung memperkuat putusan Pengadilan Negeri Bandung yang menolak keberatan dari pihak kreditur yang mendalilkan bahwa putusan BPSK yang membatalkan perjanjian kredit antara perusahaan leasing dengan kreditur seharusnya batal demi hukum karena sengketa yang terjadi bukanlah sengketa yang menjadi kewenangan BPSK dimana hubungan hukum antara Penggugat dan Tergugat, ternyata adalah didasarkan pada perjanjian pembiayaan bersama

${ }^{11}$ Anik Entrianti, (2017). Arbitrase Dalam Sistem Hukum Di Indonesia, AN-NISBAH, Vol. 03, No. 02, Tulungagung, p.280. 
dengan penyerahan milik secara fidusia, yang menerapkan hubungan hukum perdata dan tidak termasuk sengketa konsumen, sebagaimana dimaksud dalam ketentuan Undang Undang Nomor 8 Tahun 1999 tentang Perlindungan Konsumen, oleh karenanya Badan Penyelesaian Sengketa Konsumen Kota Bandung tidak berwenang untuk mengadilinya. Hal ini karena sengketa yang timbul dari pelaksanaan perjanjian pembiayaan konsumen tersebut menurut Mahkamah Agung merupakan sengketa perjanjian yang mana hal tersebut merupakan kewenangan dari Pengadilan Negeri.

Putusan Mahkamah Agung menerima putusan dari Pengadilan Negeri Bandung bahwa BPSK tidak berwenang memeriksa dan mengadili perkara tersebut. Hal ini karena telah terjadi kesepakatan antara Pemohon dan Termohon keberatan dalam perkara a quo telah terikat dalam Perjanjian Pembiayaan Konsumen yang mana dalam perjanjian tersebut antara Pemohon dan Termohon keberatan telah sepakat memilih Pengadilan Negeri Jakarta Pusat untuk menyelesaikan apabila terdapat perselisihan antara Pemohon dan Termohon keberatan, sehingga BPSK Kota Bandung menjadi tidak berwenang untuk menyelesaikan sengketa antara Pemohon dan Termohon keberatan, sehingga menurut penulis bahwa putusan Mahkamah Agung telah tepat. Hal ini berarti bahwa menurut peneliti bahwa Pengadilan Negeri Bandung menyatakan BPSK tidak berwenang terkait sengketa yang diajukan bukan sengketa konsumen melainkan sengketa perdata dan tempat pengajuan pengaduan sengketa yang seharusnya di Pengadilan Negeri Jakarta bukan di BPSK Kota Bandung.

Menurut penulis bahwa Putusan BPSK tidak berwenang dikarenakan BPSK dalam memutus tidak melihat kepada tugas dan kewenangannya sehingga pengadilan menyatakan BPSK telah melampaui kewenangannya dalam memutus perkara terkait wanprestasi. Dimana perkara terkait wanprestasi merupakan sengketa perdata bukan sengketa konsumen. Apabila Pemohon dan Termohon telah sepakat dalam perjanjian tertulis untuk menyelesaikan perkara di Pengadilan Negeri tempat kedudukan konsumen, tetapi akhirnya konsumen mengajukan gugatan ke BPSK yang berada di Kota Bandung, dan BPSK Kota Bandung tersebut kemudian menangani dan menyelesaikan perkara tersebut, maka dalam hal ini Pengadilan Negeri Jakarta dapat menyatakan bahwa BPSK tidak mempunyai kewenangan untuk menyelesaikan sengketa konsumen tersebut, hal tersebut karena penyelesaian sengketa haruslah persetujuan kedua belah pihak.

Mahkamah Agung dalam memutus sengketa ini sudah tepat bahwa BPSK tidak berwenang, karena tempat pengajuan pengaduan sengketa bahwa antara pihak termohon dan pemohon telah sepakat dalam perjanjian pembiayaan konsumen untuk menyelesaikan sengketa antara PT. Firstindo Finance Cabang Bandung dan Neva Rahmansyahpara pihak di Pengadilan Negeri Jakarta, hal ini sesuai dengan Pasal 1338 KUHPerdata yaitu setiap perjanjian menjadi hukum yang mengikat bagi para pihak yang melakukan perjanjian. Menurut Asas pacta sunt servanda menyatakan bahwa, suatu perjanjian yang dibuat berlaku mengikat bagi para pihak yang membuatnya. ${ }^{12}$ Asas ini dapat diimplikasikan dalam setiap perjanjian yang dibuat pihak tidak memandang bentuk, jenis dan isi dari perjanian, sehingga setiap perjanjian wajib dilaksanakan oleh pihak-pihak baik dalam segi hak, kewajiban dan

\footnotetext{
12 Boer Mauna, (2003). Hukum Internasional, Pengertian, Peran, Dan Fungsi Dalam Era Dinamika Global, Bandung: PT. Alumi, p.153.
} 
ketentuan-ketentuan yang diatur didalamnya. ${ }^{13}$ Menurut Harry purwanto, apapun bentuk, nama, atau siapa pihak yang membuat perjanjian tidak akan mengurangi sifat mengikat perjanjian tersebut terhadap pihak-pihak yang bersangkutan. ${ }^{14}$ Maka dalam hal ini penyelesaian sengketa merupakan kewenangan pengadilan negeri bukan kewenangan BPSK yang berarti bahwa BPSK Kota Bandung tidak berwenang untuk menyelesaikan perkara tersebut melainkan kewenangan dari Pengadilan Negeri Jakarta karena telah adanya kesepakatan antara kedua belah pihak.

\section{Kesimpulan}

Putusan Mahkamah Agung Nomor 210 K/Pdt.Sus- BPSK/2015 dalam kasus pperdata khusus sengketa konsumen antara PT First Indo American Leasing Cabang Bandung ("First Indo Finance") dengan BPSK Kota Bandung dan Neva Rahmansyah, SE menyatakan bahwa Mahkamah Agung menolak permohonan kasasi dari Pemohon Kasasi PT First Indo American Leasing Cabang Bandung ("First Indo Finance") tersebut dan memperbaiki amar putusan Pengadilan Negeri Bandung Nomor 461/Pdt.G/2014/PN Bdg. tanggal 24 Desember 2014 sehingga amar selengkapnya bahwa Mahkamah Agung menerima eksepsi turut termohon dan menyatakan BPSK tidak berwenang memeriksa dan mengadili perkara ini serta menghukum Pemohon Kasasi/Pemohon untuk membayar biaya perkara dalam tingkat kasasi yang ditetapkan sebesar Rp 500.000,00 (lima ratus ribu rupiah);

Pertimbangan Hakim Mahkamah Agung yang menyatakan bahwa BPSK tidak berwenang memutuskan perkara dalam kasus antara perusahaan pembiayaan dengan konsumen karena hubungan hukum antara Penggugat dan Tergugat merupakan perjanjian pembiayaan bersama dengan penyerahan milik secara fidusia, yang menerapkan hubungan hukum perdata dan tidak termasuk sengketa konsumen sebagaimana Ketentuan Undang Undang Nomor 8 Tahun 1999 tentang Perlindungan Konsumen sehingga sengketa yang timbul dari pelaksanaan perjanjian pembiayaan konsumen merupakan sengketa perjanjian yang merupakan kewenangan dari Pengadilan Negeri.

\section{Daftar Rujukan}

Asyhadie, Z. (2005). Hukum Bisnis Prinsip dan Pelaksanaannya di Indonesia, Jakarta: PT. Raja Grafindo Persada.

Barkatullah, A. H (2008). Hukum Perlindungan Konsumen "Kajian Teoritis dan Perkembangan Pemikiran. Bandung: Nusa Media.

Entrianti, A. (2017). Arbitrase Dalam Sistem Hukum Di Indonesia, AN-NISBAH, Vol. 03, No. 02, Tulungagung,

Fuady, Mr. (2014). Hukum Tentang Pembiayaan, Cet.5, Bandung:PT Citra Aditya Bakti.

Jamil, N K. (2020). Implikasi Asas Pacta Sunt Servanda Pada Keadaan Memaksa (Force Majeure) Dalam Hukum Perjanjian Indonesia, Jurnal Kertha Semaya, Vol. 8 No. 7 , Bali.

\footnotetext{
${ }^{13}$ Nury Khoiril Jamil, (2020). Implikasi Asas Pacta Sunt Servanda Pada Keadaan Memaksa (Force Majeure) Dalam Hukum Perjanjian Indonesia, Jurnal Kertha Semaya, Vol. 8 No. 7, Bali, p.1045.

${ }^{14}$ Harry Purwanto, (2009). Keberadaan Asas Pacta Sunt Servanda Dalam Perjanjian Internasional, Mimbar Hukum, Vol. 21, No. 1, p. 159.
} 
Manalip,Demy A.A. (2017). Perlindungan Hukum Terhadap Konsumen dalam Penarikan Kendaraan Bermotor yang Dilakukan oleh Perusahaan. Lex Administratum, E-Jurnal UNSRAT, Vol. V No. 3, Manado, Sulawesi Utara.

Mauna,Boer. (2003). Hukum Internasional, Pengertian, Peran, Dan Fungsi Dalam Era Dinamika Global, Bandung, PT. Alumi.

Miru, Ahmadi dan Sakka Pati. (2009). Hukum Perikatan: Penjelasan Makna Pasal 1233 Sampai 1456 BW, Jakarta: Rajawali Pers.

Muhammad, A. (1992). Perjanjian Baku Dalam Praktek Perusahaan Perdagangan. Bandung:PT. Citra Aditya Bakti.

Nindarwanti,K. (2012), Implementasi Program Penertiban Pemakaian Tenaga Listrik (P2TL) PT PLN (Persero) Distribusi Jawa Tengah Dan D. I. Yogyakarta di Kota Semarang. Artikel Skripsi. Semarang: Fakultas Ilmu Sosial dan Ilmu Politik Universitas Diponegoro Semarang

Nugroho, S.A. (2008). Proses Penyelesaian Sengketa Konsumen Ditinjau Dari Hukum Acara Serta Kendala Implementasinya, Jakarta: Kencana.

Purwanto,H. (2009). Keberadaan Asas Pacta Sunt Servanda Dalam Perjanjian Internasional, Mimbar Hukum, Vol. 21, No. 1.

Rohmah, U. (2014). Perikatan (Iltizam) Dalam Hukum Barat Dan Islam, Jurnal Al-Adl, Vol. 7 No. 2, Kendari.

Shofie, Y. (2009). Perlindungan Konsumen \& Instrumen-Instrumen Hukumnya, Bandung: Citra Aditya Bakti.

Simatupang, R.B. (2003), Aspek Hukum Dalam Bisnis, Cet.2, Jakarta, Rineka Cipta.

Sumantri,F. S. dkk, (2013). Penyelesaian Sengketa Antara PT. Astra Credit Companies dengan Konsumen dalam Perjanjian Leasing, Diponegoro Law Review, Vol. 1 No 3, Malang.

Suryawan, I K. (2013). Studi Komparasi Beban Biaya Atas Pemakaian Tenaga Listrik Dengan Layanan Listrik Reguler dan Layanan Listrik Prabayar, Jurnal Logic,Vol. 13. No. 3, Bali.

Sutopo,HB. (2002). Metode Penelitian Kualitatif, Surakarta: UNS Press. 